\title{
The development of the reflective practitioner through digital storytelling
}

\author{
Jane Challinor* \\ School of Social Sciences, \\ Nottingham Trent University, \\ Burton Street, Nottingham NG1 4BU, UK \\ Email: jane.challinor@ntu.ac.uk \\ *Corresponding author
}

\section{Victoria I. Marín}

Department of Applied Pedagogy and Educational Psychology, University of the Balearic Islands, Cra. de Valldemossa km 7.5, 07122 Palma de Mallorca, Spain

Email: victoria.marin@uib.es

\section{Gemma Tur}

Department of Applied Pedagogy and Educational Psychology, University of the Balearic Islands,

Calvari, 1, 07800 Ibiza, Spain

Email: gemma.tur@uib.es

\begin{abstract}
This paper presents a multiple case study on the use of digital storytelling to support the development of reflection and digital skills in professional education. Students from two universities, one group studying health and social care, the other training to be teachers, were asked to produce two artefacts, at the beginning and end of their respective modules, in which they reflected on the aspects of professional and personal learning. The artefacts, some of which were produced in groups, others by individual students, were analysed for recurring themes, levels of reflection and digital competence, particularly in the use of open educational resources. Findings from the analysis support the use of digital storytelling methods to develop a range of key skills pertinent to professional education in general but concluded that the deeper levels of reflection may be most evident in individual artefacts produced in the later stages of professional education. The study provides some important insights for teaching and learning in professional education as it suggests that digital storytelling provides a highly engaging way of introducing both reflective and open educational practices.
\end{abstract}

Keywords: digital artefacts; digital competence; digital storytelling; higher education; lifelong learning; open educational resources; professional development; professional identity; reflection; reflective practitioner.

Reference to this paper should be made as follows: Challinor, J., Marín, V.I. and Tur, G. (201X) 'The development of the reflective practitioner through digital storytelling', Int. J. Technology Enhanced Learning, Vol. XX, No. YY, pp.XXX-XXX. 
Biographical notes: Formerly a Senior Manager in the NHS, Jane Challinor has worked in Higher Education since 2006 managing programmes of study for both undergraduates and postgraduates in health and social care. In 2013, she received the Vice Chancellor's Award for Inspirational Teaching at NTU and she was recently made a Senior Fellow of the Higher Education Academy. Jane teaches research and academic skills to first-year students and leads a final-year module in leadership and team working. Jane's research interests are in the area of technology enhanced learning, student engagement and social media, which she writes about in her blog - The Virtual Leader.

Victoria I. Marín received her $\mathrm{PhD}$ in Educational Technology from the University of the Balearic Islands (UIB), Spain. She works as an Associate Lecturer in the Department of Applied Pedagogy and Educational Psychology of UIB and is a Researcher in the Educational Technology Group of the same university. She is also a Member of the Association for the Development of Educational Technology and New Technologies Applied to Education (EDUTEC). Victoria's research interests include e-Learning, Personal Learning Environments, Teacher Training, Professional Development, Personal Learning Networks, Web 2.0 for Education, Virtual Learning Platforms, Social Networking and Knowledge Management tools.

Gemma Tur received her $\mathrm{PhD}$ in Educational Technology from the University of the Balearic Islands (UIB), Spain. She works as an Associate Lecturer in the Department of Applied Pedagogy and Educational Psychology of UIB and collaborates in research in the Educational Technology Group of the same university. She is coordinator of diverse programs in the Ibiza off-campus centre such as Early Childhood, Primary and Secondary Teacher Education courses and the Open Senior University. Her research interests include e-portfolios and Personal Learning Environments, social media for learning and technology enhanced learning in Teacher Education.

\section{Introduction}

It has long been acknowledged that the development of reflective practice, as a process of learning through and from experience in order to gain new insights into self and/or practice, is important for practitioners as a part of their professional development (Finlay, 2008; Moon, 2013; Osterman and Kottkamp, 1993; Schön, 1983). Reflection is considered to be a way of developing professional judgement and of fostering the development of both a personal and a professional identity (Finlay, 2008; Copeland, 2012; Ryan and Ryan, 2013; Jamissen and Skou, 2010; Stewart, 2012). Reflection is also related to the development of practitioners' self-awareness and critical thinking (Finlay, 2008). It helps practitioners to link theory and practice and promotes self-regulation and autonomy in learner (Zimmerman and Schunk, 1989). These are important skills for lifelong learning, as some learning theories propose. For instance, heutagogy considers the adult learner as the main agent for his/her own learning development, and self-direction and effective use of tools and information as the essential elements of selfagency (Hase and Kenyon, 2000, 2007). 
Another set of lifelong learning skills relates to the use of digital technology for professional, social and personal use. With the emergence of Web 2.0, the ability to create and share information digitally has become increasingly central to professional roles (Albion, 2008; Kamel Boulos and Wheeler, 2007). The digital story is a prime example of user-created, repurposed content, in which open educational resources (OER) are exploited to create digital and multimodal stories (Copeland, 2012; Jamissen and Skou, 2010).

In this study, the authors aimed to investigate the affordances of multimodal digital storytelling for developing digital skills and supporting reflective learning in professional education, as posited by Jamissen and Skou (2010). A case study methodology is employed to develop some general proposals about the value of such pedagogical interventions in different disciplines and different stages of the students' learning journey, building on earlier research (Tur, Challinor and Marín, 2016). The participants in the study were all either future teachers or health and social care practitioners, for whom the need to act and to think professionally was an integral part of their learning throughout the course of their studies (Jonas-Dwyer, Abbott and Boyd, 2013; Mann, Gordon and MacLeod, 2009).

\section{Background}

\subsection{Reflective practice}

Reflective practice is where the practitioner makes meaning from a given situation so that he/she can better understand the art of his/her professional practice (Nurul, Haslee and Kyriacou, 2015). It consists of two parts: knowing-in-action, that is, the professional knowledge that practitioners actually use, and reflection-in-action (Schön, 1983), which involves reflecting on that professional knowledge (Schön, 1995) in order that it is simultaneously critically examined, reformulated and tested in further action. Therefore, it can be seen as a process in which the development of professional knowledge and the improvement of practice occurs together (Bruce Ferguson, 2012).

Reflective practice has been considered to hold a significant position in the professional development of pre-service teachers (Nurul, Haslee and Kyriacou, 2015), and of future health and social care practitioners (Mann, Gordon and MacLeod, 2009), both of whom are the subjects of this study.

We often assume that students, the future practitioners, possess the capacity for selfreflection (Mulder and Dull, 2014), although as Ryan and Ryan (2013) point out, reflection is not intuitive and educators need to consider where and how students will be introduced to reflective practice. Furthermore, as Boud and Walker (1998) advise, reflection needs to be put into a professional context where students can understand the link between the activity and their future professional career.

Ryan and Ryan (2013) offer a useful framework for considering the appropriateness of specific pedagogical interventions or activities at each stage of professional development (from foundational to professional practice), but as Stewart (2012) found, even well-planned activities and assessments can meet with a lack of enthusiasm from students. Jamissen and Skou (2010) propose the use of a multimodal artefact, a digital 
story, which involves the senses in different ways, engaging both producer and audience on an emotional level.

However, assessing the level of reflection in an artefact can also be problematic. A number of different scales have been proposed (Bain et al., 2002 in Ryan and Ryan, 2013; Hatton and Smith, 1995 cited in Fook, Gardener and White, 2006).

Moon has written extensively (Moon, 1999, 2004, 2013; Moon and Fowler, 2008) about the development of the skill of reflection, particularly in relation to professional practice. Moon's (1999) Map of Learning is helpful in that it describes students' representation of their learning on five progressive levels: Noticing, Making Sense, Making Meaning, Working with Meaning and Transformative Learning (Figure 1). According to Moon (1999), a process of reflection has to have taken place between levels in order for students to move from one level to another. It is therefore possible to state that reflection has happened by assessing the level of representation of learning even when the work itself is not explicitly 'reflective'.

Figure 1 Adaptation of Moon's (1999) Map of learning (see online version for colours)

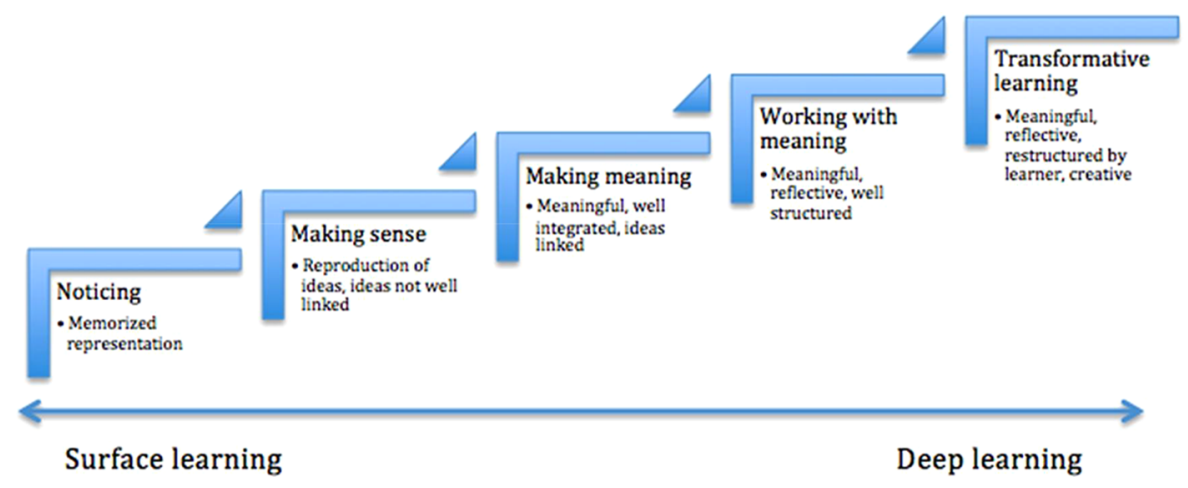

In general, reflection first happens between Making Meaning and Working with Meaning, as up to that point the new learning is simply being accommodated within existing cognitive structures.

Further repeated and deliberate reflection could then potentially take students from this point to the level of Transformative Learning.

It is this highest level of learning that is the goal of higher education in general and professional education in particular, as it is at this level that students begin to question their assumptions and to act on the insights they have gained (Mezirow, 2006) which is the prerequisite for the autonomous exercise of professional judgement in problematic, 'real-world' situations.

\subsection{Digital competence and skills}

As defined by Ala-Mutka, Punie and Redecker (2008), digital literacy consists of the ability to access digital media and Information and Communication Technologies (ICT), in order to understand and critically evaluate content and communicate effectively in a variety of contexts.

Digital competence permits the confident and critical use of ICT for employment, lifelong learning, self-development and participation in society. In order to equip students 
with the essential 21 st century skills, the integration of ICT into everyday learning is pivotal, enhancing the skills of inquiry and knowledge creation, analytical and critical thinking, creativity and the capacity to work both independently and collaboratively (Niemi and Multisilta, 2015).

Teachers and health and social care practitioners can be said to require specific skill sets in regard to digital competence (Albion, 2008; Kamel Boulos and Wheeler, 2007). In the case of teachers, they need to be digitally competent to support both the teaching and learning of ICT from the first stages in education in primary education as well as their own professional development (Castañeda and Adell, 2011). The European Community has made recommendations concerning advanced digital competences in both initial teacher training and in-service training to enable pedagogical innovation (Ala-Mutka, Punie and Redecker, 2008). The recommendations state that teacher training should consider aspects of using ICT both as a learning tool within subject teaching, for example, by designing ICT-enriched learning experiences, and as a tool for coursework and learning-related activities outside school settings, where learners can develop transferable, lifelong digital skills.

The potential of digital technology to enhance the lives of people with care and support needs is something that health and social care practitioners increasingly need to be aware of. Skills for Care (2014), for example, states that the workforce in adult social care needs to be able to use digital technology with confidence and to promote its appropriate use by people with care and support needs and their careers. A number of care organisations use social media platforms to reach vulnerable groups, disseminate information and help those with care and support needs to exercise choice and live more independently and service users are increasingly taking to social media to campaign, network and inform themselves (Linders, 2012).

In order to make digital technology accessible to all and to enhance both the production and consumption of media as important aspects of online environments (Niemi and Multisilta, 2015), the use of OER is essential. The concept of OER derives from the open source philosophy and refers to media that are freely available on the internet and with few restrictions on their reuse (Hylén, 2005); for example, individuals are able to use, adapt, reuse and build upon a resource, with the provision that the original creator is recognised as the author of his/her work. OER can be learning content (courses, learning objects), tools (to support the development, use, reuse and delivery of learning content) or implementation resources (intellectual property licences to promote open publishing of materials) (OECD, 2007). Implementation resources, amongst which Creative Commons licences are perhaps the best known (http://creativecommons.org), enable the free use and reuse of resources and thus support the rapid growth of OER.

Digital stories are multimodal artefacts in which written text, images, spoken language, music and sound are combined, creating meaning and involving the senses in many different ways (Jamissen and Skou, 2010). By building a digital storytelling artefact using social media platforms and OER, students are required to work both autonomously and collaboratively, apply digital skills and bring to bear both creativity and analytical and critical thinking. According to Robin (2008), the creation of digital stories could help develop different skills important for the 21 st century, such as digital literacy, global literacy, visual literacy and information literacy.

Combining the transformative power of narrative with the ease-of-use of emerging technologies (Hall, 2012), students have the potential to become highly engaged in the process of their own learning (Niemi and Multisilta, 2015). With the increasing 
prevalence of multimedia technologies in recent years, Cheng and Chan (2009) show that an alternative to text-mediated reflective practice, especially digital video, can help foster learner self-reflection, especially in an e-portfolio environment, where users have access to a range of digital and web-based technology. In another study by Ivala et al. (2013), in which the authors used a digital storytelling strategy with pre-service student teachers, it was found that the production of digital stories encouraged self-reflection, deep learning and higher order thinking skills.

\section{Methodology}

\subsection{The research design}

For this exploratory study, a multiple case study approach was employed. Case studies, as Yin (2003) explains, are generalisable to theoretical propositions and not to populations or universes, and their main aim is to expand and generalise theories rather than to enumerate frequencies. In multiple case studies, we ask the same questions of the different cases but compare the answers to reach conclusions. Evidence based on multiple cases can be considered more solid and convincing than single case studies (Castro, 2010). One of the strategies that can be applied to multiple cases is analytical comparison. Using this strategy, the researcher observes and compares different cases for similarity or differences (Tójar and Mena, 2011).

This collective case study comprised five cases which varied in terms of size of cohort, stage of educational study, discipline, module theme and host country of the higher education institution (Table 1 in Context for details). Through these cases, we explored the affordances of multimodal digital storytelling for developing digital skills and supporting reflective learning in future teachers and health and social care professionals. Comparisons were made to highlight common phenomena (convergences) but also differences between cases that might relevant for the topic under consideration.

Table 1 The context for each case

\begin{tabular}{llllll}
\hline & \multicolumn{1}{c}{ Case 1 } & \multicolumn{1}{c}{ Case 2 } & \multicolumn{1}{c}{ Case 3 } & \multicolumn{1}{c}{ Case 4 } & \multicolumn{1}{c}{ Case 5 } \\
\hline Size of & 129 (Artefact & 93 (Artefact 1 & 20 (Artefact 1 & 15 (Artefact & 73 (Artefact 1 \\
cohort & $1 n=33 ;$ & $n=34 ;$ & $n=5 ;$ Artefact & $1 n=2 ;$ & $n=23 ;$ \\
(number of & Artefact 2 & Artefact 2 & $2 n=5)$ & Artefact $2 n$ & Artefact 2 \\
artefacts) & $n=103$ ) & $n=86)$ & & $=5$ ) & $n=24$ ) \\
Level of & Undergraduate & Undergraduate & Undergraduate & Postgraduate & $\begin{array}{l}\text { Undergraduate } \\
\text { third year, }\end{array}$ \\
study and & first year, & third year, & first year, first & (Masters) & first semester, \\
length of & whole year, & whole year, & semester, & first & teacher \\
module, & health and & health and & teacher & semester, & teacher \\
discipline & social care; & social care, & education, & teacher & education, \\
and & research and & leadership and & didactics and & education, & technology in \\
module & study skills & teamwork & curriculum & educational & education \\
theme & (UK) & (UK) & (Spain) & contexts and & (Spain) \\
(country) & & & & processes & \\
& & & & (Spain) & \\
\hline
\end{tabular}


Table 1 The context for each case (continued)

\begin{tabular}{|c|c|c|c|c|c|}
\hline & Case 1 & Case 2 & Case 3 & Case 4 & Case 5 \\
\hline $\begin{array}{l}\text { Initial level } \\
\text { of digital } \\
\text { skill }\end{array}$ & $\begin{array}{l}\text { Limited } \\
\text { knowledge of } \\
\text { constructing } \\
\text { OER within } \\
\text { the course } \\
\text { curriculum }\end{array}$ & $\begin{array}{l}\text { Limited } \\
\text { knowledge of } \\
\text { constructing } \\
\text { OER within } \\
\text { the course } \\
\text { curriculum }\end{array}$ & $\begin{array}{l}\text { No previous } \\
\text { experience of } \\
\text { constructing } \\
\text { OER within } \\
\text { the course } \\
\text { curriculum }\end{array}$ & $\begin{array}{l}\text { No previous } \\
\text { experience } \\
\text { of } \\
\text { constructing } \\
\text { OER within } \\
\text { the course } \\
\text { curriculum }\end{array}$ & $\begin{array}{l}\text { Have } \\
\text { previously } \\
\text { created digital } \\
\text { artefacts using } \\
\text { OER within } \\
\text { the course } \\
\text { curriculum }\end{array}$ \\
\hline $\begin{array}{l}\text { Knowledge } \\
\text { of } \\
\text { reflective } \\
\text { practice }\end{array}$ & $\begin{array}{l}\text { First } \\
\text { introduction to } \\
\text { reflection for } \\
\text { majority of } \\
\text { students }\end{array}$ & $\begin{array}{l}\text { Students had } \\
\text { developed a } \\
\text { good } \\
\text { understanding } \\
\text { of reflective } \\
\text { practice } \\
\text { through } \\
\text { previous } \\
\text { modules }\end{array}$ & $\begin{array}{l}\text { First } \\
\text { introduction to } \\
\text { reflection for } \\
\text { majority of } \\
\text { students }\end{array}$ & $\begin{array}{l}\text { First } \\
\text { introduction } \\
\text { to reflection } \\
\text { for majority } \\
\text { of students }\end{array}$ & $\begin{array}{l}\text { First } \\
\text { introduction to } \\
\text { reflection for } \\
\text { majority of } \\
\text { students }\end{array}$ \\
\hline $\begin{array}{l}\text { Specifics } \\
\text { about the } \\
\text { learning } \\
\text { activity }\end{array}$ & $\begin{array}{l}\text { The creation } \\
\text { of the digital } \\
\text { artefact on } \\
\text { their learning } \\
\text { was embedded } \\
\text { as an activity } \\
\text { to develop } \\
\text { their ICT } \\
\text { skills and } \\
\text { reflect on their } \\
\text { learning } \\
\text { during the } \\
\text { course }\end{array}$ & $\begin{array}{l}\text { For the second } \\
\text { artefact, } \\
\text { students had } \\
\text { to add a voice- } \\
\text { over }\end{array}$ & $\begin{array}{l}\text { For the second } \\
\text { artefact, } \\
\text { students had } \\
\text { to reflect on } \\
\text { the first one } \\
\text { and identify in } \\
\text { what sense } \\
\text { their identity } \\
\text { as future } \\
\text { teachers had } \\
\text { changed and } \\
\text { write an } \\
\text { individual } \\
\text { post in their } \\
\text { e-portfolio } \\
\text { reflecting on } \\
\text { that artefact }\end{array}$ & $\begin{array}{l}\text { Same as in } \\
\text { Case } 3\end{array}$ & $\begin{array}{l}\text { The creation } \\
\text { of the digital } \\
\text { artefact on } \\
\text { their learning } \\
\text { was embedded } \\
\text { as an activity } \\
\text { to develop } \\
\text { their ICT } \\
\text { skills and } \\
\text { reflect on their } \\
\text { learning } \\
\text { during the } \\
\text { course }\end{array}$ \\
\hline \multirow[t]{2}{*}{$\begin{array}{l}\text { Software } \\
\text { options } \\
\text { (Table 2) }\end{array}$} & $\begin{array}{l}\text { Artefact 1: } \\
\text { Photopeach }\end{array}$ & $\begin{array}{l}\text { Same as in } \\
\text { Case } 1\end{array}$ & $\begin{array}{l}\text { Photopeach or } \\
\text { a video editing } \\
\text { software }\end{array}$ & $\begin{array}{l}\text { Same as in } \\
\text { Case } 3\end{array}$ & $\begin{array}{l}\text { Free rein to } \\
\text { choose tools } \\
\text { and format }\end{array}$ \\
\hline & $\begin{array}{l}\text { Artefact 2: } \\
\text { free rein to } \\
\text { choose tools } \\
\text { and format. } \\
\text { Those selected } \\
\text { include } \\
\text { PowerPoint, } \\
\text { Knovio, Prezi, } \\
\text { WeVideo, } \\
\text { Photopeach, } \\
\text { SmileBox and } \\
\text { YouTube }\end{array}$ & & & & $\begin{array}{l}\text { Artefact 1: } \\
\text { tools used } \\
\text { included } \\
\text { Linoit, } \\
\text { Glogster, } \\
\text { Photopeach, } \\
\text { Thinglink and } \\
\text { Padlet } \\
\text { Artefact 2: } \\
\text { Photopeach, } \\
\text { Kizoa, } \\
\text { Present.me or } \\
\text { a video editing } \\
\text { software }\end{array}$ \\
\hline
\end{tabular}




\subsection{Context}

The students involved $(n=330)$ were all undertaking undergraduate courses or postgraduate courses either as health and social care practitioners or as future primary or secondary teachers, at universities in UK and in Spain. The sample was a purposive one, based on all students in each of the modules taught by the three lecturers who carried out the study.

The comparison between the UK and Spanish students was interesting chiefly because of recent statistics published on internet access, use and activities published by Eurostat (2016). For example, the numbers of citizens with above average digital skills is $40 \%$ in UK and 30\% in Spain; the percentage of households with access to the internet (in 2014) was also higher in UK: $90 \%$ in UK compared to $74 \%$ in Spain, whilst the number of households having access to desktop and portable computers was $86 \%$ in UK compared to $67 \%$ in Spain. However, an initial survey of the digital skills of students in UK (Case 1) suggested that, notwithstanding superior access to the internet, they were no more likely than their Spanish counterparts to be experienced in the use and creation of OER as only $37 \%$ had experience in this area.

All the students followed the same process, which consisted of creating two digital stories, one at the beginning and the second at the end of the module, but there was some variation in the tools that students used (Table 2) and in the mode of assessment (group or individual). In all cases, this learning activity was a compulsory task that the students had to complete as a mandatory part of the module assessment.

Table 2 Software options for the creation of the digital artefacts

\begin{tabular}{|c|c|c|}
\hline $\begin{array}{l}\text { Software } \\
\text { options }\end{array}$ & Capabilities & Digital artefact \\
\hline $\begin{array}{l}\text { Photopeach } \\
\text { and } \\
\text { Smilebox }\end{array}$ & $\begin{array}{l}\text { Create slideshows by uploading photographs, adding } \\
\text { captions and selecting a music soundtrack }\end{array}$ & Slideshow \\
\hline Powerpoint & $\begin{array}{l}\text { Create visual presentations including different } \\
\text { multimedia elements and text }\end{array}$ & Slideshow \\
\hline $\begin{array}{l}\text { Knovio and } \\
\text { Present.me }\end{array}$ & $\begin{array}{l}\text { Create video presentations by recording online } \\
\text { presentations with microphone or webcam }\end{array}$ & Video presentation \\
\hline Prezi & $\begin{array}{l}\text { Create online visual non-linear presentations including } \\
\text { different multimedia elements and text }\end{array}$ & $\begin{array}{l}\text { Non-linear } \\
\text { presentation }\end{array}$ \\
\hline WeVideo & $\begin{array}{l}\text { Make and edit online videos by uploading different } \\
\text { media }\end{array}$ & Video \\
\hline Youtube & $\begin{array}{l}\text { Edit online videos by including different media and } \\
\text { upload them }\end{array}$ & Video \\
\hline MovieMaker & $\begin{array}{l}\text { Make and edit videos offline (then can be shared on } \\
\text { Youtube) }\end{array}$ & (Offline) Video \\
\hline $\begin{array}{l}\text { Linoit, } \\
\text { Glogster and } \\
\text { Padlet }\end{array}$ & $\begin{array}{l}\text { Create an online poster or wall/corkboard by including } \\
\text { different media (videos, images and text) }\end{array}$ & Poster/corkboard/wall \\
\hline Thinglink & $\begin{array}{l}\text { Create different digital interactive contents by adding } \\
\text { rich media links to photos and videos }\end{array}$ & $\begin{array}{l}\text { Interactive images } \\
\text { and videos }\end{array}$ \\
\hline Kizoa & $\begin{array}{l}\text { Create slideshow in a video form including text, effects } \\
\text { and music }\end{array}$ & Video slideshow \\
\hline
\end{tabular}


In the first artefact, students worked together in small groups to create an online slideshow incorporating music, images and words. The focus of the artefact was an articulation of professional values aimed at answering the question "What sort of teacher/health and social care practitioner do I want to be?" As this question has general relevance to all students, the artefact was constructed, in each case, in small groups. This encouraged students to debate values and reach an agreement on those they held in common.

In the second artefact, students reflected on their learning during the module through the creation of a digital story. In both cases, students were encouraged to use OERs by incorporating media licenced under Creative Commons and hosting their presentations on open platforms. Some instruction on the ethical usage of open resources, including searching for and correctly attributing media, formed part of the preparation in each module. In this instance, the theme of the artefact was a reflection on learning, which is more specific to the individual. For this reason, although in three cases $(3,4,5)$ the second artefact was created in a group, students were additionally required to create an individual e-portfolio post. In Cases 1 and 2, the digital artefacts were all created individually.

\subsection{Data collection and analysis}

The creation of two digital artefacts, one at the start and the second at the end of the module, allowed the authors to gauge the progress students made in the development of digital competences and levels of reflection on their learning. Prior to the start of the academic year, the teachers of the modules collaborated on the design of learning activities and assessment rubrics which would be used in all five instances.

The data were mainly obtained through the digital artefacts themselves but also from e-portfolio posts the students were required to submit in some cases. The analysis was basically qualitative, using the above-mentioned rubrics to assess the level of reflection and digital competence, and thematic analysis was used to identify common themes and topics within both digital stories and e-portfolio posts. The assessment rubric in respect of levels of reflection on learning was based on Moon's levels of representation of learning (Moon, 1999) (Table 3). Assessment of digital competence was based on the sophistication of the tool used as well as competence in its use, inclusion of spoken word and music, and the incorporation of OER and their correct attribution. For the levels of digital competence shown in the artefacts, a three-level rubric was used (Table 4).

Table 3 Rubric for the levels of reflection based on Moon (1999)

\begin{tabular}{ll}
\hline Noticing (Level 1) & $\begin{array}{l}\text { Students choose an inappropriate image or defined the value incorrectly, } \\
\text { indicating they have not yet correctly assimilated the information }\end{array}$ \\
$\begin{array}{l}\text { Making sense } \\
\text { (Level 2) }\end{array}$ & $\begin{array}{l}\text { Students organise the professional values and beliefs they have identified } \\
\text { and illustrate them with an image and a simple definition, but without } \\
\text { making connections to other learning }\end{array}$ \\
$\begin{array}{l}\text { Making meaning } \\
\text { (Level 3) }\end{array}$ & $\begin{array}{l}\text { Student fit the new ideas or concepts into contexts previously studied or } \\
\text { experienced and are beginning to think about future practice }\end{array}$ \\
Working with & $\begin{array}{l}\text { Students start to make connections with other areas of learning } \\
\text { meaning (Level 4) } \\
\text { Transformative } \\
\text { learning (Level 5) }\end{array}$ \\
$\begin{array}{l}\text { Students may begin here to evaluate their own frame of reference or even } \\
\text { the process of knowing itself. Students observe the change in their } \\
\text { learning and views on education }\end{array}$ \\
\hline
\end{tabular}


Table 4 Rubric for the levels of digital competence

\begin{tabular}{ll}
\hline Low & Students use software that has limited functionality (usually slideshows \\
instead of videos) or use them very poorly \\
There is no audio or it is of bad quality \\
Images are pixelated or of bad quality \\
Open licences have not been respected/considered \\
Students use more of the functions or options of the software chosen \\
In most cases, there is a combination of music/audio, images and text but \\
the quality some of the elements could be improved \\
There are mistakes in the usage of open licences \\
The artefacts combine music/audio, images and text \\
Students have considered, and made greater use of the full potential of the \\
software chosen (e.g. embedded video, animations, voice-over) \\
Open licences have been considered and correctly used when adding third \\
party resources to the artefact
\end{tabular}

\section{Discussion and findings}

\subsection{The reflective process}

\subsubsection{Artefact one}

For the first artefact, the students were asked to research professional codes and values, to state their own personal values, or those they aspired to in their imagined future profession, and to illustrate these with an appropriate image and soundtrack.

Unless students chose an inappropriate image or defined the value incorrectly, in which case they could be said to be at the stage of Noticing, they were assumed to be already at the stage of Making Sense (Level 2). At this stage, the words used in captions may be taken directly from the material studied and then paraphrased either in single words, for example: 'patient' and 'honest' (Case 5); 'respect' (Case 3), or short phrases: 'Empathy - show understanding' (Case 1); 'guiding students' (Case 3).

At the level of Making Meaning (Level 3), some examples might be: "patients and staff should be treated with dignity and respect as it improves overall safety, experience and outcomes when all individuals feel valued, supported and empowered" (Case 2); "inclusive education as education for all without any exception" and "we teachers need to be updated both in psychological and digital aspects" (Case 5); or "we want to encourage debate, dialogue and participation" (Case 3).

At the next level, Working with Meaning (Level 4), students start to make connections with the use of theory, their personal experience of working in the field or an articulation of personal views. In Case 4 , for example, one group of students presented a contrast between the education of the past ('rigid teachers and demotivated pupils') with 'the (digital) tools of the future', linking experience and aspiration in order to articulate personal values. 
The highest level, Transformative Learning (Level 5), was not in evidence in the first artefact in any of the cases studied, possibly because the work was generally very brief and possibly also because it did not explicitly call for any form of introspection. As Ryan and Ryan (2013) also suggest, this higher order of learning may occur only after some practice.

\subsubsection{Artefact two}

In the second artefact, the final-year and postgraduate students did generally go on to demonstrate a higher level of learning and reflection. In part, this may be due to additional teaching input about reflective practice and theory, which occurred throughout the module. Another factor to consider, however, is the nature of the task itself: arguably, the richness of this representation of their learning, through a digital story, makes it possible for a deeper level of reflection to emerge (Jamissen and Skou, 2011). Certainly, there was a noticeable link between levels of creativity, digital skill and reflection as higher levels of reflection were mostly noted in those artefacts which displayed higher levels of digital skill. As in the first artefact, all students were able to demonstrate the first level of learning, Noticing. There follow some examples from each of the other four levels.

Level 2 - Making Sense. Student 'A' (Case 2) produced a final digital story which was largely descriptive and composed of fairly generalised thoughts and feelings about events that occurred during a period of work experience, e.g. "it was interesting to see what teachers do on a day to day basis". She described events, feelings or thoughts but was not connecting the experience to other concepts or seeing its relevance to future practice. Similarly, Case 5 (Group 10) describes the feelings and new impressions that they have regarding ICT after completing the module, but they do not connect these with future practice, e.g. "ICT enables us to enhance each learning activity using different tools".

Level 3 - Making Meaning. Student ' $D$ ' (Case 2) focuses in one section on the development of her communication skills: "I have always felt conscious of my pronunciation because English is not my first language. When we did our presentation, I wrote my script and kept practising. On the day, I was terrified, but I read my script and it went off well". The student here gives a specific example and shows an understanding of the motivation behind her behaviour and how she consciously set about changing this. In another examples, Group 24 (Case 5) created a final artefact in which they explained their work process during the course: "The ideas of the three students about education concerning ICT changed thanks to their involvement in the course and the new ways of working that this course provided them, where each student has to be the author of their own learning process".

Level 4 - Working with Meaning. Student ' $T$ ' (Case 2) focused on the importance of collaborative learning, connecting experience with concepts: "working in groups enabled me to realise a fuller sense of self - by reflecting on my reactions, emotions and contributions when working with others ... just as I had learned in my studies, reflective practice enabled me to develop by making a conscious effort to think about what happened, making links to theory and observing others' practices".

Level 5 - Transformative Learning. Student 'C' (Case 4) begins her personal blog with: "This long path in which I have immersed myself started when I decided to join the world of education, and questions have not stopped flowing in my head since!" and 
concludes: "I have learned that there exist methodologies outside of my own traditional learning experience - of memorizing and reproducing knowledge .... I have learned the importance of meaningful assessment, tools that make the classroom more dynamic, and that the emotional state of both teacher and pupil affects performance ... the feeling of a slow and silent revolution in education."

\subsubsection{Discussion}

The greatest progression seen in reflective skill, between first and final artefacts, was in the final-year Health and Social Care and in the postgraduate teaching students. The number of artefacts in Case 4 are very small overall but it was still notable that two groups showed evidence of moving from Making Sense in artefact 1 to Transformative Learning in the second artefact. In Case 2, the evolution was especially marked, with many more artefacts achieving Level 4 (Working with Meaning) (an increase of 30\%) and even a small number (just two) reaching Level 5 (Transformative Learning). This fits with the model described by Ryan and Ryan (2013) where reflective skill develops on a continuum between the foundational level of professional education and professional practice itself. The students in Case 5, however, did not appear to have developed much in terms of reflective skills, principally because they tended to remain focused on the use of digital tools, which was the theme of the module, rather than on the process of reflection.

Students in the foundational levels of their professional education, as in Cases 1 and 3 , also did not show much evidence of development in reflective ability. In Case 1, only $12 \%$ of artefacts reached Level 4 and none Level 5 . One semester or even a whole academic year is possibly too short a timescale in which to see progress to the highest levels, especially for students with little or no actual experience of the profession and with few opportunities to make those 'repeated and deliberate' acts of reflection which Moon (1999) sees as essential to bring about transformative learning.

\subsection{Digital skills and OER construction}

As previously explained, in each case, the procedure for the creation of the digital artefact was similar, but the tools that students could use were different. Students generally were given more freedom to choose the tool used for the second artefact.

In Case 1, all groups succeeded in using the selected tool relatively easily for their first artefact and had no trouble in sourcing and correctly citing OERs (music and images). By the time they came to create their final digital artefact, they demonstrated some anxieties about finding and referencing copyright free images and three students uploaded images, and a further three music soundtracks, which did not meet the OER standard. In terms of software tools, most of them used Prezi or Powerpoint. In one case, the artefact was not posted online and so did not qualify as an OER. Other tool choice can be seen in Figure 2. Overall, the majority of students showed increased sophistication in their choice of presentation tool and in the sourcing of OERs. By adding and editing soundtrack and voice-over, using the added functionality of Prezi, or embedding video and animations, they also demonstrated increased skill and confidence in the use of online platforms. 
Figure 2 Number of artefacts per software tool for the final digital artefact (Case 1) (see online version for colours)

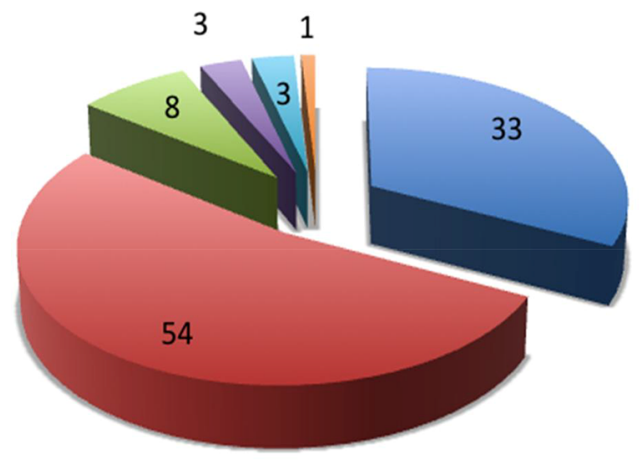

\author{
- Powerpoint \\ a Prezi \\ Knovio \\ Photopeach \\ WeVideo/Movie Makr \\ Tumblr
}

In Case 2, all groups succeeded in using Photopeach relatively easily for their first artefact and had little trouble in sourcing and correctly citing OERs (music and images). In the second artefact, only one student included an image that violated copyright. In terms of skill and confidence in creating online content, most students (over 60\%) showed a desire to use more complex platforms such as Prezi. A total of 22 students also demonstrated which also demonstrated high levels of digital skill such as the use of animations in PowerPoint (although these were not posted online and do not qualify as OER), animations and embedded video in Prezi, and the creation of skilfully edited videos, incorporating both images and live action, which went far beyond anything that had been taught in the module. Although this could indicate that the first artefact was over simplified for this group through the restriction to a single platform, in reality some students, particularly those whose first language was not English, and most of the mature students, still found the first artefact a challenge because they lacked confidence in their ability to create online content. These same students also needed further coaching to enable them to complete the reflective digital story but all succeeded in doing so. In most cases, the final digital story made direct reference to this aspect of their learning and to their pride in their achievement.

In Case 3, the first artefact was constructed using video editing software and was then uploaded to YouTube. The comparison of first and second artefacts showed a slight improvement in Creative Commons licence usage. The use of correct citation of resources also increased in the second artefacts.

In Case 4, all artefacts were created using Photopeach, a simple web-based slideshow tool. Final artefacts included resources with correct citation of the Creative Commons licences. The fact that most final objects also included the authors' own photographs (four out of five) is largely due to the experience of using photo-based networks in other learning activities during the semester.

Considering that they did not have any workshops on the use of digital tools, we can assume in both Cases 3 and 4 that students had sufficient previous experience of using video editors and social media even though they had limited experience of their use for learning purposes.

In Case 5, for the first artefact at the start of the year, most of the student groups (19 from 23) selected the simplest option, Linoit, which did not require complex ICT skills. The others used Photopeach, PowerPoint and Glogster. All groups succeeded in using the 
tools relatively easy but some had trouble in sourcing and correctly citing OERs (music, video and images) and several used resources that did not meet the OER standard.

For the final artefact, as was mentioned before, students could choose to use a slideshow or a video or animation to create a story or narrative of their learning. Most of the artefacts were created using the video format, especially Movie Maker and shared on YouTube. Probably because they had worked on an educational video just before this task, they were familiar with creating and editing videos. Other tools choice can be seen in Figure 3. Students mainly used their own photos of themselves or screenshots from their e-portfolios and seemed to be more aware of copyright issues than in the first artefact, some of them providing details of the Creative Commons licence (three groups).

Figure 3 Number of artefacts per software tool for the final digital artefact (Case 5) (see online version for colours)

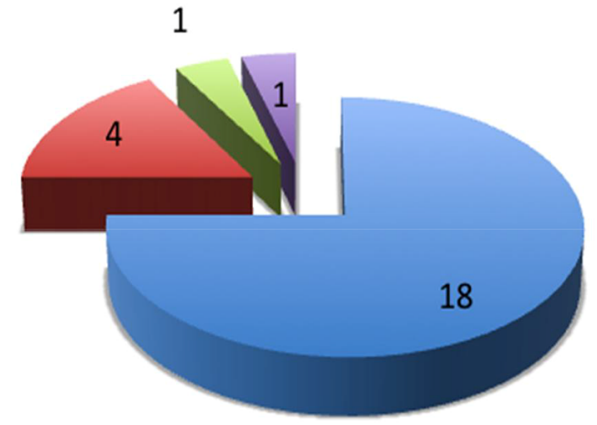

MovieMaker \& Youtube

Photopeach

Kizoa

Woogle Presentation

It is difficult to compare the evolution in the ICT skills level from the first artefact to the final one in Case 5, since they were each created in very different formats. However, students improved their digital skills during the process, especially in relation to the creating and editing of videos.

Overall, students tended to move from a simple tool with limited functionality to increasingly complex platforms which they chose to use for the first time. This demonstrates the students' increased confidence in online content creation and exploration of new tools. The use of personal photographs, the addition of animations and evidence of sophisticated video editing techniques in many cases are an indication not only of the level of digital skill involved, which was higher from the first artefact to the second, but also of individual and group creativity in the development of the artefacts. In addition, the correct citation of OER resources and the use of Creative Commons licences, which occurred more often in the final artefact than in the first one, is a good indicator that students' understanding of attribution and copyright also improved.

\section{Conclusion}

The use of OER and digital platforms has many benefits for both teachers and health and social care practitioners. The fact that the storytelling artefact both uses and is built as an OER introduces students to the philosophy of openness and collaboration, which has the potential to promote the habit and the skills of lifelong learning, as recommended in UNESCO's World OER Congress (2012). Openness as a philosophy is strongly aligned 
to ideas of citizen empowerment in health and social care, which manifests itself in the increased use of open platforms for campaigning and information exchange by those with care and support needs (Linders, 2012).

For student teachers, there is a particular advantage in a lived experience as learners of innovative learning practices that may encourage them in turn to embrace innovation in their future teaching careers, whilst learning about OER is a step towards future Open Educational Practice as claimed by Misra (2014).

In the process of producing their own learner-driven content, students acquire important 21 st century competences such as knowledge creation, analytical and critical thinking, creativity and self-regulated learning, and digital and information literacy (Niemi and Multisilta 2015; Robin, 2008).

In terms of reflection, the artefacts in this multiple case study demonstrated that deeper levels of self-awareness and emotional engagement were apparent when constructed on an individual basis rather than in groups. Furthermore, the highest levels of learning (according to Moon, 1999) were more likely to be reached by 'mature' students, whether that means older in years, having greater practical experience of work settings or simply more advanced in their level of education. However, the group-based activities, including those carried out by students at the start of their module, supported the development of other key skills, in particular, collaborative working and agreement on common values for their future profession.

The development of reflective skills is clearly important for students who will go on to work in environments which require an awareness of self and other as well as the autonomous exercise of professional judgement (Finlay, 2008; Moon, 2013; Osterman and Kottkamp, 1993; Schön, 1983; Zimmerman and Schunk, 1989). It is clear, however, as Ryan and Ryan (2013) point out that these skills are not innate and must be scaffolded through well-crafted pedagogical interventions, over a period of time.

Combining digital technologies with reflective tasks has a number of advantages, in particular, the potential for eliciting higher levels of creativity and self-expression. At the same time, the ability to create and share information digitally has become increasingly central to professional roles (Albion, 2008; Kamel Boulos and Wheeler, 2007). Through the construction of a multimodal artefact (Jamissen and Skou, 2010) with its combination of images, words and music, students can convey an emotional depth rarely encountered in the more traditional forms of reflective essay or portfolio. This tends to confirm the findings of Cheng and Chan (2009) and Ivala et al. (2013) that the creation of digital stories encourages self-reflection, deep learning and higher order thinking skills.

\section{References}

Ala-Mutka, K., Punie, Y. and Redecker, C. (2008) Digital Competence for Lifelong Learning, Office for Official Publications of the European Communities, Luxembourg. Available at: $\mathrm{ftp}: / / \mathrm{ftp} . j \mathrm{rc} . \mathrm{es} / \mathrm{pub} / \mathrm{EURdoc} / E U R d o c / J R C 48708 . T N . p d f$ [access 16 January 2016] [online].

Albion, P.R. (2008) 'Web 2.0 in teacher education: two imperatives for action [online]', Computers in the Schools: Interdisciplinary Journal of Practice, Theory, and Applied Research, Vol. 25, Nos. 3-4, pp.181-198. Available at: http://www.tandfonline.com/doi/abs/10.1080/ 07380560802368173 [access 21 December 2015].

Bain, J.D., Ballantyne, R., Mills, C. and Lester, N.C. (2002) Reflecting on practice: Student teachers' perspectives, Post Pressed, Flaxton. 
Boud, D. and Walker, D. (1998) 'Promoting reflection in professional courses: the challenge of context', Studies in Higher Education, Vol. 23, No. 2, pp.191-207. [online] Available at: http://www.tandfonline.com/doi/abs/10.1080/03075079812331380384 [access 21 December 2015].

Bruce Ferguson, P. (2012) Becoming a Reflective Practitioner, Hamilton, New Zealand.

Castañeda, L. and Adell, J. (2011) 'El desarrollo profesional de los docentes en entornos personales de aprendizaje (PLE)', in Roig Vila, R. and Laneve, C. (Eds.): La práctica educativa en la Sociedad de la Información: Innovación a través de la investigación /La pratica educativa nella Società dell'informazione: L'innovazione attraverso la ricerca, Marfil, Alcoy, pp.83-95.

Castro, E. (2010) 'El Estudio de Casos como Metodología de Investigación y su Importancia en la Dirección y Administración de Empresas [online]', Revista Nacional de Administración, Vol. 1, No. 2, pp.31-54. Available at: http://dialnet.unirioja.es/descarga/articulo/3693387.pdf [access 16 January 2016].

Cheng, G. and Chau, J. (2009) 'Digital video for fostering self-reflection in an ePortfolio environment [online]', Learning, Media and Technology, Vol. 34, No. 4, pp.337-350. Available at: http://www.tandfonline.com/doi/abs/10.1080/17439880903338614?journalCode $=$ cjem 20 [access 16 January 2016].

Copeland, S. (2012) 'Daffodil terrorism: the dangers of homogenised storytelling', CIRN Prato Community Informatics Conference, Prato, Italy, pp.7-9 November 2012. [online] Available at: http://ccnr.infotech.monash.edu/assets/docs/prato2012docs/copeland.pdf [access 21 December 2015].

Eurostat. (2016) Computers and the internet in households and enterprises. [online] Available at: http://ec.europa.eu/eurostat/web/information-society/data/main-tables [access 16 January 2016].

Finlay, L. (2008) Reflecting on "Reflective Practice”, PBPL paper 52 (January), pp.1-27. Available at: www.open.ac.uk/pbpl

Fook, J., Gardner, F. and White, S. (Eds.) (2006) Critical Reflection in Health and Social Care, Open University Press, Maidenhead.

Hall, T. (2012) 'Digital renaissance: the creative potential of narrative technology in education [online]', Creative Education, Vol. 3, No. 1, pp.96-100. Available at: http://dx.doi.org/10.4236/ce.2012.31016 [access 28 September 2015].

Hase, S. and Kenyon, C. (2000) From andragogy to heutagogy. ultiBASE [online]. Available at: http://www.psy.gla.ac.uk/ steve/pr/Heutagogy.html [access 16 January 2016].

Hase, S. and Kenyon, C. (2007) 'Heutagogy: a child of complexity theory [online]', Complicity: An International Journal of Complexity and Education, Vol. 4, No. 1, pp.111-118. Available at: https://ejournals.library.ualberta.ca/index.php/complicity/article/view/8766/7086 [access 16 January 2016].

Hatton, N. and Smith, D. (1995) Reflection in Teacher Education: Towards Definition and Implementation, The University of Sydney, School of Teaching and Curriculum Studies.

Hylén, J. (2005) Open Educational Resources: Opportunities and Challenges. OECD Report [online]. Available at: http://www.oecd.org/edu/ceri/37351085.pdf [access 28 September 2015].

Ivala, E., Gachago, D., Condy, J. and Chigona, A. (2013) 'Digital storytelling and reflection in higher education: a case of pre-service student teachers and their lecturers at a university of technology [online]', Journal of Education and Training Studies, Vol. 2, No. 1, pp.217-227. Available at: http://redfame.com/journal/index.php/jets/article/view/286 [access 28 September 2015].

Jamissen, G. and Skou, G. (2010) 'Poetic reflection through digital storytelling - a methodology to foster professional health worker identity in students [online]', Seminar.net, Vol. 6, No. 2. Available at: http://seminar.net/volume-6-issue-2-2010/152-poetic-reflection-through-digitalstorytelling-a-methodology-to-foster-professional-health-worker-identity-in-students [access 28 September 2015]. 
Jonas-Dwyer, D.R.D., Abbott, P.V. and Boyd, N. (2013) 'First reflections: third-year dentistry students' introduction to reflective practice [online]', European Journal of Dental Education: Official Journal of the Association for Dental Education in Europe, Vol. 17, No. 1, pp.64-69. Available at: http://www.ncbi.nlm.nih.gov/pubmed/23279416 [access 10 January 2016].

Kamel Boulos, M.N. and Wheeler, S. (2007) 'The emerging Web 2.0 social software: an enabling suite of sociable technologies in health and health care education [online]', Health Information and Libraries Journal, Vol. 24, No. 1, pp.2-23. Available at: http://www.ncbi.nlm.nih.gov/pubmed/17331140 [access 10 January 2016].

Linders, D. (2012) 'From e-government to we-government: Defining a typology for citizen coproduction in the age of social media [online]', Government Information Quarterly, Vol. 29, pp.446-454. Available at: http://www.sciencedirect.com/science/article/pii/ S0740624X12000883 [access 28 September 2015].

Mann, K., Gordon, J. and MacLeod, A. (2009) 'Reflection and reflective practice in health professions education: a systematic review [online]', Advances in Health Sciences Education, Vol. 14, No. 4, pp.595-621. Available at: http://link.springer.com/10.1007/s10459-007-9090-2 [access 10 January 2016].

Mezirow, J. (2006) 'An overview of transformative learning', in Sutherland, P. and Crowther, J. (Eds.): Lifelong Learning, Routledge, London, pp.24-38.

Misra, P.K. (2014) 'Online training of teachers using OER: Promises and potential strategies [online]', Open Praxis, Vol. 6, No. 4, pp.375-385. Available at: http://openpraxis.org/index.php/OpenPraxis/article/view/155 [access 28 September 2015].

Moon, J. (1999) Reflection in Learning and Professional Practice, Routledge, Oxford, UK.

Moon, J. (2004) 'Using reflective learning to improve the impact of short courses and workshops [online]', Journal of Continuing Education in the Health Professions, Vol. 24, No. 1, pp.5-11. Available at: http://onlinelibrary.wiley.com/doi/10.1002/chp.1340240103/pdf [access 28 September 2015].

Moon, J. (2013) Reflection in Learning and Professional Development: Theory and Practice, Routledge, London and New York.

Moon, J. and Fowler, J. (2008) 'There is a story to be told'; A framework for the conception of story in higher education and professional development [online]', Nurse Education Today, Vol. 28, No. 2, pp.232-239. Available at: http://www.sciencedirect.com/science/article/ pii/S0260691707000718 [access 28 September 2015].

Mulder, C. and Dull, A. (2014) 'Facilitating self-reflection: the integration of photovoice in graduate social work education [online]', Social Work Education, Vol. 33, No. 8, pp.1017-1036. Available at: http://www.tandfonline.com/doi/full/10.1080/ 02615479.2014.937416 [access 28 September 2015].

Niemi, H. and Multisilta, J. (2015) 'Digital storytelling promoting twenty-first century skills and student engagement [online]', Technology, Pedagogy and Education, Vol. 24, No. 5. Available at: http://www.tandfonline.com/doi/abs/10.1080/1475939X.2015.1074610 [access 28 September 2015].

Nurul, W., Haslee, E. and Kyriacou, C. (2015) 'Reflective practice on instructional planning: relevance and contribution to pre-service teachers' professional development [online]', IJAEDU- International E-Journal of Advances in Education, Vol. I, No. 3, pp.211-217. Available at: http://ijaedu.ocerintjournals.org/article/view/5000163368 [access 10 January 2016].

OECD. (2007) Giving Knowledge for Free. The Emergence of Open Educational Resources. OECD Publishing, Paris. [online] Available at: http://www.oecd.org/edu/ceri/38654317.pdf [access 28 September 2015].

Osterman, K.F. and Kottkamp, R.B. (1993) Reflective Practice for Educators: Improving Schooling through Professional Development. Corwin Press, Inc., Newbury Park, CA. 
Robin, B.R. (2008) 'Digital storytelling: a powerful technology tool for the 21 st century classroom [online]', Theory into Practice, Vol. 47, No. 3, pp.220-228. Available at: http://www.tandfonline.com/doi/full/10.1080/00405840802153916 [access 28 September 2015].

Ryan, M. and Ryan, M. (2013) 'Theorising a model for teaching and assessing reflective learning in higher education [online]', Higher Education Research \& Development, Vol. 32, No. 2, pp.244-257. Available at: http://www.tandfonline.com/doi/abs/10.1080/07294360.2012. 661704 [access 28 September 2015].

Schön, D. (1983) The Reflective Practitioner, Jossey-Bass, San Francisco, CA.

Schön, D. (1995) 'Knowing-in-action: the new scholarship requires a new epistemology [online]', Change: The Magazine of Higher Learning, Vol. 27, No. 6, pp.27-34. Available at: $\mathrm{http} / /$ www.tandfonline.com/doi/abs/10.1080/00091383.1995.10544673?journalCode=vchn20 [access 23 March 2016].

Skills for Care. (2014) Digital Working, Learning and Information Sharing: A Workforce Development Strategy for Adult Social Care. [online]. Available at: http://www. skillsforcare.org.uk/Document-library/Skills/Digital-literacy/Digital-Working-Learning-andinformation-Sharing-Strategy-WEB.pdf [access 28 September 2015].

Stewart, J. (2012) 'Reflecting on reflection: increasing health and social care students' engagement and enthusiasm for reflection [online]', Reflective Practice: International and Multidisciplinary Perspectives, Vol. 13, No. 5, pp.719-733. Available at: http://www.tandfonline.com/doi/abs/10.1080/14623943.2012.670627 [access 28 September 2015].

Tójar, J.C. and Mena, E. (2011) 'Innovaciones educativas en el contexto andaluz. Análisis multicaso de experiencias en Educación Infantil y en Educación Primaria [online]', Revista de Educación, Vol. 354, pp.499-527. Available at: http://www.revistaeducacion.educacion.es/ re354/re354_20.pdf [access 10 January 2016].

Tur, G., Challinor, J. and Marín, V.I. (2016) 'Digital artefacts for reflection on identity in teacher education', Reflecting Education, Vol. 10, No. 1, pp.4-24. Available at: http://www. reflectingeducation.net/index.php/reflecting/article/view/133 [access 3 October 2016].

UNESCO World OER Congress. (2012) 2012 Paris OER Declaration, UNESCO, Paris. [online] http://www.unesco.org/new/fileadmin/MULTIMEDIA/HQ/CI/CI/pdf/Events/Paris\%20OER\% 20Declaration_01.pdf [access 28 September 2015].

Yin, R. (2003) Case Study Research: Design and Methods, 3rd ed., Sage, London.

Zimmerman, B.J. and Schunk, D.H. (Eds.) (1989). Self-Regulated Learning and Academic Achievement: Theory, Research and Practice, Springer-Verlag, New York. 